\title{
Packaging: Materials Science for All of Us
}

Milk is contained in either a cardboard box or a plastic jug. Cereal is in a box and soup in a can. Why? Does the packaging material make a difference? These are the types of questions that lead students from kindergarten to 12th grade to focus on materials science and materials technology.

Materials properties, marketing, manufacturing, and cost are relevant to the development of packaging of retail goods. Teachers may find many ways to use these concepts in their classrooms, depending on the grade level. An elementary teacher can take a class to the grocery store and collect samples for analysis and simple testing. In high school, students can research these points and develop an analysis that focuses on the relationship of material properties with their uses, then carry out experiments such as the measurement of heat loss through a foam plastic hamburger container versus a paper one.

Our recent elementary-teacher workshop on the subject of Developing and Evaluating Curricula in Elementary Science Education, held at the Highline School District, Burien, WA in July 1996 focused on teaching materials properties as related to package design. The participants collected many ways that various grocery products are packaged, as listed in the Table. The participants easily determined 5-10 ways that these and other products are packaged.

The next question for the participants to address is why the products are packaged in so many different ways. Clearly, marketing plays a large role, but cost is also an important factor. Cost per unit weight of the different items indicates the importance of cost versus marketability. Packaging material can also be related to the shelf life of the product. Other variables include the degree of processing (The cereal is sugar-coated) and transparency (To see is to believe).

The teacher workshop on packaging materials provides the following:

- an introduction to technology and its interdependence on science and engineering; - a history of materials in packaging and related technologies;

- definitions and careers (e.g., who does what in technology applications?);

- structure, properties, and processing relationships in materials;

- materials selection activities (i.e., taking apart the packages for selected products to see what materials are used and to analyze why); and

- engineering design and its relationship to materials selection, including factors of

Table: Examples of packaging found in the grocery store for four products.

\begin{tabular}{llll}
\hline Soup & Popcorn & Coffee & Fruit Juice \\
\hline "tin" can & cardboard box & coffee can & rigid plastic \\
glass jar & plastic bag & plastic-lined paper & waxed cardboard \\
styrofoam & coated paper & fiber bags & foil box \\
rigid plastic cup & rigid plastic jar & foil brick & metal can \\
foil-lined cardboard & glass jar & glass jar & glass jar \\
flexible plastic bag & paper bag & rigid plastic jar & cardboard tube \\
rigid plastic jar & plastic box & cardboard "can" & plastic bottles \\
\hline
\end{tabular}

cost, manufacturability, and availability.

The participants are given specific assignments with suggestions for their use with different grade levels, including a field trip to the grocery store. The participants also conduct a case study on cans and bottles in regards to their design, manufacture, and use in common retail products.

The historical end of package development ${ }^{1}$ is an important component as it helps in integrating the science and social science curriculum in the school, which is a current concern of educators. Whereas in the past available materials were used for containment of products, materials now are designed and developed specifically for the packaging of products. The historical sequence of materials for packaging might be as follows: (1) shells, coconuts; (2) wooden bowls; (3) woven baskets; (4) animal skin bladders; (5) clay pots; (6) glass containers, (7) paper and cardboard, (8) metals; (9) plastics; and (10) composites.

Increasing science literacy among the general public must start early in the school system. This packaging activity, and many like it, can be used to bring science and technology to a level where it can be understood and appreciated by all, which is a specific goal delineated in the National Science Education Standards ${ }^{2}$ and

Education Exchange highlights experiences of scientists and engineers with local schools (K-12), community programs, and university programs, along with helpful hints and resources. If you would like to share your own involvement in science education, contact MRS Bulletin, Materials Research Society, 9800 McKnight Road, Pittsburgh, PA 15237-6006; fax 412-367-4373; e-mail Bulletin@mrs.org. in Benchmarks for Science Literacy..$^{3}$ A variety of ways to provide applied materials science activities as motivational and learning tools have been collected recent$1 y^{4,5}$ but the lack of teacher education in science (and especially materials) is an impediment to implementation. This materials packaging unit developed for the classroom provides one resource for educators, scientists, and engineers alike to implement in schools from kindergarten to 12th grade and in communities to assist teachers and to develop local programs to motivate students to learn and appreciate science.

Thomas G. StOEBE AND Charles W. Wright

Thomas G. Stoebe is a professor of materials science and engineering at the University of Washington. In addition to his research in the area of optical and electronic materials, he has developed and participated in a variety of materials-related curriculum projects for $K-12$. He may be reached at Department of Materials Science and Engineering, University of Washington, Seattle, WA 98195-2120. Charles W. Wright teaches physics, biology, and the Battelle-PNNLdeveloped materials science and technology course at Bethel High School, near Tacoma, WA. He may be reached at Science Department, Bethel High School, 22215-38th Ave. E., Spanaway, WA 98387. Specific materials developed for classroom use in our packaging unit may be obtained from the authors (e-mail. stoebe@u.washington.edu):

\section{References}

1. E.N. Kaufmann, "Packaging," MRS Bulletin 21 (11) (1996), p. 96.

2. National Research Council, National Science Education Standards (National Academy Press, Washington, DC, 1996).

3. American Association for the Advancement of Science, Project 2061, Benchmarks for Science Literacy (Oxford University Press, New York, 1993).

4. T. Stoebe and W. Huebner, eds., Innovative Ideas in Ceramics and Materials Curricula (American Ceramic Society, Westerville, $\mathrm{OH}$, 1996).

5. List of Educational Aides and Direct Sources ("LEADS List") (ASM International, Materials Park, OH, 1996). 